\title{
Herbicide Residues in Agroecosystems: Fate, Detection, and Effect on Non-Target Plants
}

\author{
Mohammad Mehdizadeh $^{1 *}$, Waseem Mushtaq ${ }^{2}$, Shahida Anusha Siddiqui ${ }^{3,4}$, Sawsen Ayadi ${ }^{5}$, \\ Pervinder Kaur ${ }^{6}$, Stephen Yeboah ${ }^{7}$, Sargol Mazraedoost ${ }^{8}$, Duraid K.A.AL-Taey ${ }^{9}$ and Koko \\ Tampubolon ${ }^{10}$
}

${ }^{1}$ Department of Agronomy and Plant Breeding, Faculty of Agriculture and Natural Resources, University of Mohaghegh Ardabili, Ardabil, Iran

2 Allelopathy Laboratory, Department of Botany, Aligarh Muslim University, Aligarh, 202002, India

${ }^{3}$ Technical University of Munich Campus Straubing for Biotechnology and Sustainability, Essigberg 3, 94315 Straubing, Germany

${ }^{4}$ DIL e.V.-German Institute of Food Technologies, D-Quakenbrück, Germany

${ }^{5}$ Laboratory of Genetics and Cereal Breeding, National Agronomic Institute of Tunisia, Carthage University, 43 Avenue Charles Nicole, 1082 Tunis, Tunisia

${ }^{6}$ Department of Agronomy, Panjab Agricultural University, Ludhiana, India

${ }^{7}$ CSIR Crops Research Institute, Box 3785 Kumasi, Ghana

${ }^{8}$ Biotechnology Research Center, Shiraz University of Medical Sciences, Shiraz, Iran

${ }^{9}$ Department of Horticulture, Faculty of Agriculture, University of AL-Qasim Green, Iraq

${ }^{10}$ Program Study of Agrotechnology, Faculty of Agriculture and Animal Husbandry, Universitas Tjut Nyak Dhien, Medan 20123, Sumatera Utara, Indonesia

\begin{abstract}
Environmental pollution is one of the most critical issues concerning the quality of the environment and threatens the human safety due to bioaccumulation. The extensive application of pesticides causes great public concern about the negative impacts on the environment and human health. Herbicides have been used for weed management and to prevent the yield loss of agricultural products. In recent years, the environment's quality is extensively considered due to the enormous pesticide application in agroecosystems. There are some different pathways for the degradation of herbicides in the environment, including biodegradation, chemical degradation, photodegradation, uptake by target or non-target plants, adsorption to soil particles and leaching. Assessing the environmental risks of herbicides before mass production, commercialization, and distribution is very important. The presence of herbicide residues in the environment has become a fundamental problem in many countries. Bioassay and analytical methods could identify, detect, and quantify herbicide residues in the environment. In this review paper, the fate, detection methods, and effect of herbicides on non-target plants have been discussed.
\end{abstract}

\section{Keywords \\ degradation, persistence, pesticide, toxicity}




\section{Introduction}

Today an incredible amount of agrochemicals (herbicides, insecticides, fungicides, nematicides, etc.) is used in agroecosystems to manage weeds and other pests. This extensive application of pesticides causes great public concern about the negative impacts on the environment and human health. Herbicides, as the most commonly used pesticides, can threat agricultural safety and influence the water and soil resources, human and animal health, food safety, non-target plants, and ecosystem function and structure [1-3]. In recent years, numerous incidents have been reported about the negative impacts of herbicides and their residues on different crops like cereals, vegetables, oil plants, etc. The direct damaging role of herbicides on crops is reported by some researchers in other areas and study conditions. Depending on the chemical structure of herbicides, crop species, environmental conditions, and soil properties, the negative impacts of herbicide residues could be categorized as the destruction of the plant, decrease biomass with or without recovery, and enormous crop development. However, germination, flower and seed production, and plants' vitality could be affected by herbicide residues during the critical growing steps [4]. According to these negative environmental impacts of herbicides, the use of non-chemical methods for managing weeds has received more attention in recent years [5-7]. Usually, it is complicated to distinguish between crop damage due to herbicides residues, deficiency of essential elements, inappropriate soil in terms of $\mathrm{pH}$ and salinity, insect pests, microbial, viral, fungal agents, etc. Based on herbicide mode of action and the plant species' method of use, the phytotoxicity could occur within very slow, moderate, or fast after herbicide application.

Nowadays, accurate and sensitive analytical procedures help researchers to detect the agrochemical molecules and study herbicides' non-target effects in the soil, water, and plant tissues. On the other hand, bioassays are considered a cost-effective alternative method for detecting the bioavailable portion of herbicides in the environment. Some herbicides have high or moderate persistence in the environment and can displace far away from the applied location. Herbicide residue could quickly be moved through the surface water as well as groundwater. The persistence of herbicides in the environment should be considered due to residues' potential effect on non-target crops and impose irreversible economic loss to producers [8]. However, there is a positive effect of herbicide persistence by controlling the weeds during the whole growing season, and no need to repeat the spray. The persistence time of herbicides in the environment depends on different factors such as the chemical structure of herbicides, herbicide application rate, degradation process, solubility in water, soil texture and properties, temperature, etc.

The response of different crops to herbicide residues is greatly depending on the genetic structure of plants. Plants with high genetic similarity could be having the same reaction to specific herbicides. Boutin et al. [9] examined the effects of some herbicides on other plant species. They reported that plants with different genetic properties had a different response to herbicides so that the crop species were more tolerant than non-target plants. Pesticide companies evaluate their new products' impacts in field and greenhouse conditions on different plant species, including weeds and crops from various families. During their experiments, tested plants are exposed to varying doses of herbicides under field and controlled conditions, and the tolerance or susceptibility of plants was measured. By using these experiments, the safe dose for the target plant was obtained during dose-response tests. Also, the effective doses for proper control of different weeds could be measured [10]. There are some other methods to detect and quantify herbicides from various media (soil, water, animal's body, plant tissues, human body). Generally, analytical methods such as HPLC, GC, TLC, and bioassays are important commonly used methods by researchers worldwide. This review paper aims to help researchers understand the fate and detection of herbicides from the environment and evaluate their residues' impacts on non-target plants. 


\section{Persistence and degradation}

Persistence is a commonly used term in environmental and pesticide science and refers to the continuing existence of a specific pesticide in the environment as a biologically active compound. Persistence has two negative and positive aspects. The negative aspect is associated with environmental pollution, human safety, and affecting non-target plants. However, the long-time weeds control in the field is a desirable aspect. In an ideal scenario, we expect that an applied herbicide had a favorable control effect on weeds during the whole growing season and then decompose into non-toxic and eco-friendly compounds. But practically, this is not happening in many cases, and herbicide residues remain active in the environment for a long time. Their impact on non-target organisms is not unexpected. There are many different factors affecting herbicide persistence, including herbicides' structure and nature, method of application, soil microbial activity, population, soil texture, moisture, and $\mathrm{pH}$ [11]. Pesticides with high persistence levels have the potential to contaminate water resources. As presented in Figure 1, the different main pathways for herbicide fate and degradation in the environment are including biodegradation, chemical degradation, photodegradation, uptake by target or non-target plants, adsorption of herbicide molecules by soil, leaching into the groundwater as well as surface runoff. Knowing the persistence time of an applied herbicide and its residues' probable effects on the environment is so important and should be considered. Half-life is a pivotal factor in studying the persistence and degradation of herbicides in the agroecosystems. It does refer to the time for dissipation of the initial amount of applied pesticide.

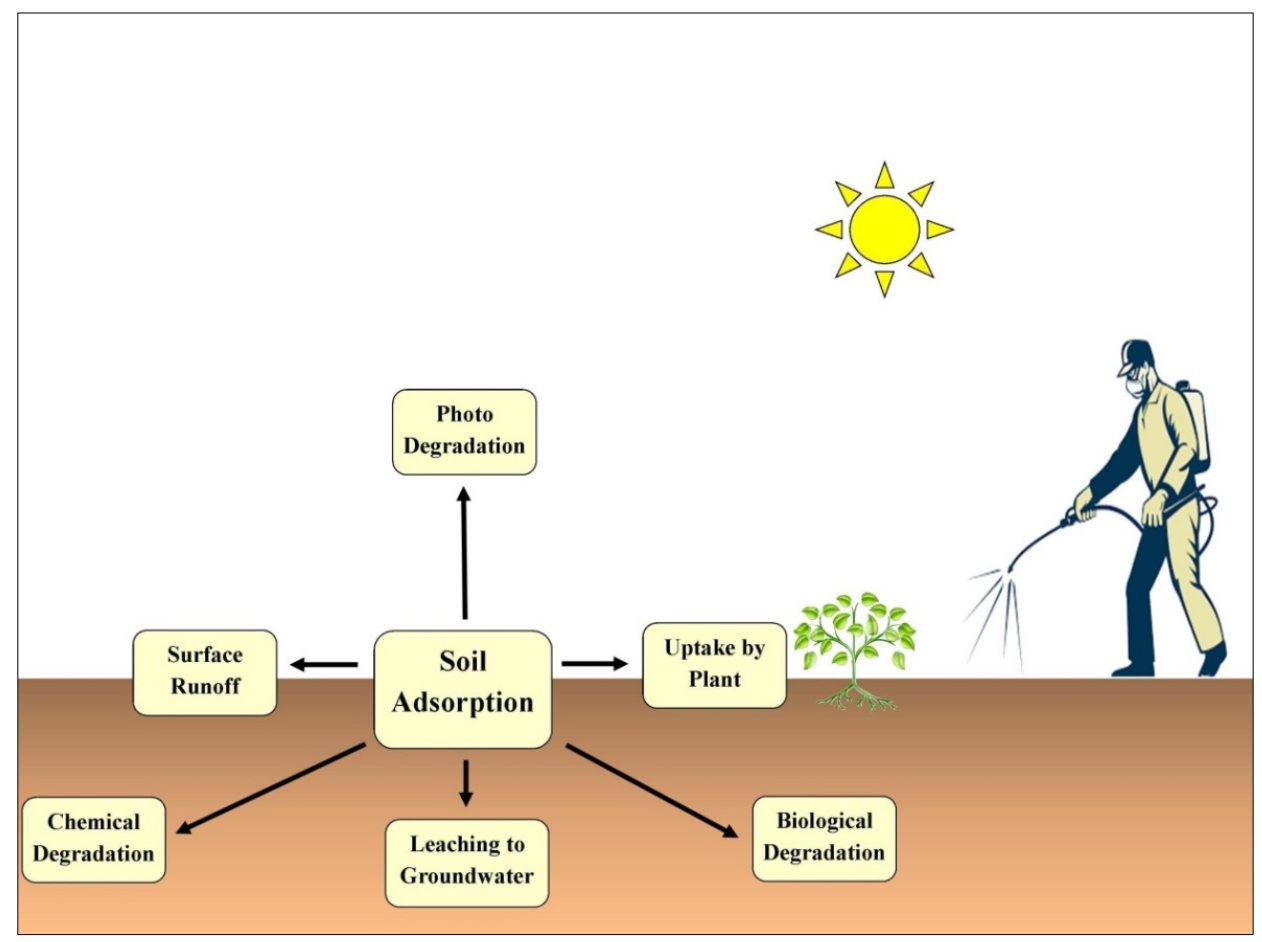

Figure 1: Different pathways for herbicide fate and degradation in the environment

\section{Main factors affecting herbicides persistence and degradation}

There are some different pathways for the degradation of herbicides in the environment, including biodegradation (degradation by microorganisms), chemical degradation (hydrolysis and oxidation), 
photodegradation (degradation due to the effect of sunlight), uptake by target or non-target plants, adsorption to soil particles and leaching [12]. Regardless of various factors affecting degradation and persistence, only a minimal amount of applied herbicide reaches the site of action [13]. The substantial remaining part will enter the environment and interact with water and soil degrades to different metabolites. Also, microorganisms' consumption as a carbon source could be considered [14].

Herbicides with a high level of persistence in the agricultural environment can remain in the soil and damage the next rotational crop. Half-life is a crucial factor for quantifying pesticides in the environment and refers to the time required to dissipate the 50 percent of pesticide in soil or water [15].

\subsection{Soil characteristics}

\subsubsection{Soil organic matter}

The soil's organic matter content has an essential role in the fate of persistent herbicides in the soil environment [16]. Generally, microorganism biomass and activity are greatly influenced by soil organic matter content. Soil with a high organic matter level had a more significant microorganism population and biomass [17]. Greater microbial activity is an optimum condition for enhanced herbicide biodegradation in the soil environment. Wu et al. [18] observed that degradation of metolachlor herbicide in soils was significantly influenced by soil organic matter content. However, soil organic matter content could be considered a binding site for herbicide molecules and their metabolites' adsorption to soil particles [19]. Mehdizadeh [20] found that the addition of organic amendments to the soil has led to a significant reduction in metribuzin half-life. Hence, the organic matter content has a dual effect on the degradation and persistence of herbicides in the soil.

\section{$3.1 .2 \mathrm{pH}$}

Soil $\mathrm{pH}$ affects herbicides' persistence by affecting the adsorption process [21]. It is related to the nature and structure of herbicides and their metabolites. Palma et al. [22] reported that soil $\mathrm{pH}$ and herbicides with acidic properties could strongly affect these herbicides' bioavailability on the soil. Quan et al. [23] found that soil $\mathrm{pH}$ significantly affected the persistence and dissipation of mesotrione herbicide in soil. On the other hand, soil pH may also affect soil microorganisms' population and the biodegradation of herbicides [24]. Singh et al. [25] showed that biodegradation of chlorpyrifos was highly dependent on soil $\mathrm{pH}$. They reported 256 days for the half-life of this herbicide in soil with $\mathrm{pH}$ 4.7. However, in soil with $\mathrm{pH}$ 5.7, the half-life was 58 days.

\subsubsection{Soil texture}

Soil texture and composition of sand, silt, and clay have an essential impact on herbicides' degradation and persistence in the soil environment. However, the understanding of this effect is very complicated [26]. Generally, the degradation of herbicides in heavy soils is faster than in light soils [27]. Kucharski and Sadowski [28] found that the degradation of ethofumesate was faster in medium silty loam soil than loamy sand soil. Wlodarczyk and Siwek [26] found that degradation of clomazone, metazachlor, and pendimethalin herbicides was not affected by soil texture.

\subsection{Environmental conditions}

Weather conditions can play an essential role in pesticide degradation in soil. Herbicides have more significant degradation in areas with high rainfall due to enhanced biological and chemical processes in the soil environment [29]. Nevertheless, Nunan et al. [30] reported that soil microbial activity was inhibited due to heavy rainfall that saturated the soil. Generally, increasing soil temperature is also associated with the increased biological activity of the soil and degradation. Cessna et al. [31] showed that degradation of metsulfuron-methyl and thiencarbazonemethyl in cold seasons was lower than in warm seasons with higher temperatures. 


\section{Risk assessments of herbicides}

Generally, the risks associated with herbicides could be discussed in two important aspects including environmental and biosafety-related risks. The contamination of drinking water, groundwater, soil resources, wildlife habitat, and microorganism's activities are among the most critical aspects of herbicide's environmental risks $[1,11]$. On the other hand, the effects of herbicides on human health through the bioaccumulation of herbicides molecules in human body is of great importance as a herbicide biosafety risk [32]. Todays' importance of chemical methods and herbicides application as one of the most critical weed management strategies is undeniable. However, the risks associated with using these chemicals and their effects on non-target organisms have become a significant environmental challenge. Therefore, assessing the environmental risks of herbicides before mass production, commercialization, and distribution is very important. International specialized agencies such as European Union and United States environmental protection agency evaluate herbicides' environmental risks and side effects. Processes such as degradation, persistence, movement, leaching, toxicity, drift, and factors related to human health and contamination of food and water resources, especially drinking water, are carefully considered. Williams et al. [32] evaluated the risk assessment of roundup herbicide. They concluded that roundup and its components do not pose a risk for the production of heritable/somatic mutations in humans. Primel et al. [33] investigated the risk assessment of water contamination by propanil herbicide residues using high-performance liquid chromatography and confirmation by gas chromatography-mass spectrometry. They reported that propanil was degraded very rapidly, and high concentrations of its metabolites were found, varying from 1.0 to $567.5 \mu \mathrm{g} \mathrm{L}^{-1}$ in water. Lu et al. [34] reported that glyphosate herbicide at high concentrations levels caused inhibition of Escherichia coli growth as a non-target organism. However, there are deficiencies for herbicide risk assessment studies. Usually, the effects of the combination of herbicides in the environment are not considered. Ensminger et al. [35] reported the persistence of combinations of different herbicide residues in urban surface waters and sediments in various California areas.

\section{Herbicides phytotoxicity and non-target organisms}

One of the most critical risks associated with the application of persistent herbicides is the toxicity effects on sensitive plant species in crop rotations. The effects of different herbicides on non-target plants are presented in Table 1. Herbicides with moderate to persistently high levels in the environment can impose toxic effects on sensitive plants [36]. The high stability of a herbicide in the soil is characterized by a half-life factor indicated for the time required to degrade and reduce the initial amount of herbicide by $50 \%$. These herbicides and their derivatives usually remain active in the environment for a long time (more than one season). Wang et al. [37] found that the residues of QYR301 as an HPPD-inhibiting herbicide at the rate of $180 \mathrm{~g}$ a.i. ha ${ }^{-1}$ had a profound phytotoxicity effect on sunflower, coriander, carrot, and radish. Different plant species exhibit different sensitivity or tolerance levels to a specific herbicide concerning biological and morphological characteristics. Arora and Tomar [38] reported that isoproturon applied at $0.75 \mathrm{~kg} \mathrm{ha}^{-1}$ did not leave the phytotoxic effect on pearl millet and wheat crops. However, the chickpea's shoot and root height and fresh and dry biomass were significantly affected by ten $\mathrm{mM}$ application of isoproturon [39]. 
Please cite this article as

Mehdizadeh et al. Reviews in Agricultural Science, 9: 157-167, 2021

https://dx.doi.org/10.7831/ras.9.0_157

Table 1: Effects of different herbicides on non-target plants

\begin{tabular}{|c|c|c|c|c|c|}
\hline Group $^{a}$ & $\mathrm{MOA}^{\mathrm{b}}$ & Herbicide & Non-target plant species & $\begin{array}{l}\text { Concentration needs to significant } \\
\text { damage }\end{array}$ & Reference \\
\hline $9 / \mathrm{G}$ & EPSPS & Glyphosate & Lupinus albicaulis & $1002 \mathrm{~g} \mathrm{ha}^{-1}$ & {$[40]$} \\
\hline $10 / \mathrm{H}$ & GS & Glufosinate & Solanum lycopersicum & $186 \mathrm{~g}$ a.i. $\mathrm{ha}^{-1}$ & {$[4]$} \\
\hline \multirow{4}{*}{$5 / \mathrm{C}$} & \multirow{4}{*}{ PSII A } & Atrazine & Pennisetum americanum & $10 \mathrm{mg} \mathrm{kg}^{-1}$ & [41] \\
\hline & & Metribuzin & Brassica napus & $1 \mathrm{mg} \mathrm{kg}^{-1}$ & [42] \\
\hline & & Prometryn & Triticum aestivum & $12 \mathrm{mg} \mathrm{kg}^{-1}$ & [43] \\
\hline & & Simazine & Avena sativa & $1.45 \mu \mathrm{g} \mathrm{kg}^{-1}$ & [44] \\
\hline $6 / \mathrm{C}$ & PSII B & Bentazon & Phaseolus vulgaris & $0.96 \mathrm{~kg}$ a.i. ha ${ }^{-1}$ & [45] \\
\hline \multirow{11}{*}{ 2/B } & \multirow{11}{*}{ ALS } & Sulfosulfuron & Brassica napus & $2.1 \mu \mathrm{g}$ a.i. $\mathrm{kg}^{-1}$ & {$[36]$} \\
\hline & & Rimsulfuron & Beta vulgaris & $0.58 \mu \mathrm{g}$ a.i. $\mathrm{kg}^{-1}$ & [46] \\
\hline & & Tribenuron-methyl & Brassica napus $L$ & $0.33 \mu \mathrm{g}$ a.i. $\mathrm{kg}^{-1}$ & {$[36]$} \\
\hline & & Metsulfuron-Methyl & Matricaria recutita & 0.058 g a.i. ha $^{-1}$ & [47] \\
\hline & & Triasulfuron & Brassica napus L. & 25 g a.i. ha-1 & {$[3]$} \\
\hline & & Nicosulfuron & Zea mays & $45 \mathrm{~g}$ a.i. $\mathrm{ha}^{-1}$ & [48] \\
\hline & & Chlorimuron & Helianthus strumosus & 4.95 g a.i. ha ${ }^{-1}$ & {$[4]$} \\
\hline & & Imazapic & Nicotiana tabaccum & $45 \mu \mathrm{M}$ & [49] \\
\hline & & Imazethapyr & Brassica juncea & $1 \mu \mathrm{g} \mathrm{g}^{-1}$ & {$[50]$} \\
\hline & & Imazapyr & Brassica oleracea & $1.12 \mathrm{~kg}$ a.i ha ${ }^{-1}$ & {$[51]$} \\
\hline & & Imazaquin & Lupinus albus & $0.28 \mathrm{~kg} \mathrm{a} . \mathrm{ha}^{-1}$ & [52] \\
\hline \multirow{4}{*}{$1 / \mathrm{A}$} & \multirow{4}{*}{ ACCase } & Quizalofop-P & Sorghum bicolor & $160 \mathrm{~g}$ a.i. $\mathrm{ha}^{-1}$ & {$[53]$} \\
\hline & & Clethodim & Sorghum bicolor & $68 \mathrm{~g}$ a.i. $\mathrm{ha}^{-1}$ & [53] \\
\hline & & Alloxydim & Solanum lycopersicum & $1.2 \mathrm{mg} \mathrm{L}^{-1}$ & {$[54]$} \\
\hline & & $\begin{array}{l}\text { Clodinafop- } \\
\text { propargyl }\end{array}$ & Chrysopogon zizanioides & $1198.8 \mathrm{mg} \mathrm{ha}^{-1}$ & {$[55]$} \\
\hline \multirow{3}{*}{$4 / \mathrm{O}$} & \multirow{3}{*}{ SA } & $2,4-\mathrm{D}$ & Phaseolus vulgaris & $0.3 \mathrm{ppm}$ & {$[56]$} \\
\hline & & Dicamba & Eupatorium perfoliatum & $5.6 \mathrm{~g} \mathrm{ha}^{-1}$ & [57] \\
\hline & & MCPA & Triticum aestivum & $>1.5 \mathrm{~L} \mathrm{ha}^{-1}$ & [58] \\
\hline \multirow{2}{*}{$3 / \mathrm{K}$} & \multirow{2}{*}{ IMA } & Trifluralin & Glycine max & $1 \mathrm{~kg} \mathrm{ha}^{-1}$ & [59] \\
\hline & & Pendimethalin & Oryza sativa & $1600 \mathrm{~g}_{\text {ai ha }} \mathrm{ha}^{-1}$ & {$[60]$} \\
\hline \multirow{3}{*}{$14 / \mathrm{E}$} & \multirow{3}{*}{$\mathrm{PPO}$} & Oxadiazon & Oryza sativa & $1 \mathrm{~kg} \mathrm{ha}^{-1}$ & {$[61]$} \\
\hline & & Oxadiargyl & Oryza sativa & $160 \mathrm{~g} \mathrm{a.i} \mathrm{ha}^{-1}$ & {$[60]$} \\
\hline & & Oxyfluorfen & Hydrangea paniculata & $0.02 \mathrm{mg} \mathrm{L}^{-1}$ & [62] \\
\hline
\end{tabular}

a'WSSA: Weed Science Society of America, ${ }^{b}$ MOA: Mode of action, EPSPS: 5-enolpyruvylshikimate-3-phosphate synthase inhibitor, GS: glutamine synthetase inhibitor, PSIIA: Inhibitor of photosynthesis at photosystem II site A, PSIIB: Inhibitor of photosynthesis at photosystem II site B, ALS: acetolactate synthase inhibitor, ACCase: acetyl-coenzyme A carboxylase inhibitor, SA: synthetic auxins, IMA: Inhibitor of microtubule assembly, PPO: protoporphyrinogen oxidase inhibitor

Generally, some crops are highly sensitive to a wide range of herbicides and are typically used as indicator plants in bioassays studies to evaluate herbicide residues' toxicity. These plants respond to the lowest concentrations of herbicides in the environment and are very useful in detecting unknown herbicide residues. As in some cases, the accuracy and sensitivity of bioassay studies with indicator plant species are comparable with chromatographic methods. Plant's species such as sugar beet, oilseed rape, soybean, tomato, chickpea, and cotton are used as the most common plant indicators in herbicides toxicity studies due to their high sensitivity. Mehdizadeh et al. [36] found that the residues of sulfosulfuron and tribenuron methyl herbicides in soil resulted in reduced oilseed rape and sugar 
beet dry biomass. However, maize and barley have less susceptibility to these herbicides. Kandel et al. [63] reported that applying different post-emergence herbicides resulted in higher phytotoxicity at different soybean growth stages than non-treated control. Villaverde et al. [54] studied the phytotoxicity of alloxydim herbicide and reported high sensitivity of tomato to this herbicide and its major byproduct. Mehdizadeh et al. [42] reported that root and shoot biomass of oilseed rape (Brassica napus L.) was severely affected by metribuzin residues in soil.

In assessing herbicides' toxicity, some unique indexes such as plant root and shoot dry and fresh biomass, plant height, root length are used. According to the literature, among these indexes, the root dry biomass of sensitive plants has been reported as the most crucial index in evaluating the phytotoxic effect of different herbicides [42]. Mehdizadeh et al. [36] found that sulfosulfuron and tribenuron methyl at different doses ranging from 0.1-5.6 $\mu \mathrm{g}$ $\mathrm{kg}^{-1}$ soil had adverse effects on root and shoot dry weight of sensitive crops such as oilseed rape (Brassica napus L.) and sugar beet (Beta vulgaris L.).

Herbicides applied in agricultural lands could target weeds as well as non-target organisms. Herbicide's residues in the environment may affect non-target crops in different ways, including growth and reproduction, changes in behavior, or even death [64-66]. In recent years, there has been increased concern regarding the safety of herbicides. Filkowski et al. [67] reported some different mutations in Arabidopsis thaliana associated with 2,4-D and dicamba herbicides application.

\section{Methods for detecting herbicide residues}

There are some different analytical methods for detecting herbicide residues in the environment. High performance liquid chromatography (HPLC) [68, 69], gas chromatography (GC) [70], thin-layer chromatography (TLC) [71], high performance liquid chromatography/mass spectrometry (HPLC-MS) [72], gas chromatography/mass spectrometry (GC-MS) [73], high performance liquid chromatography tandem mass spectrometry (HPLC-MS/MS) [74], and capillary electrophoresis [75] are from essential and commonly used analytical methods herbicide residues evaluating studies in soil. Successful detection of herbicide residues from different media has been reported using analytical methods [76, 77]. However, these methods are complicated, expensive, time-consuming, require specialized equipment, different solvents with high purity, and extraction techniques for separating herbicide residues from the soil.

Besides analytical methods, there are various bioassay methods to identify, detect, and quantify herbicide residues in the environment. In plant bioassay, as the standard type of bioassay method, sensitive plants are used as reliable bioindicators for detecting unknown concentrations of herbicides in soil [78]. These sensitive plants should be responsive to low concentrations of herbicides in the soil. Understanding and evaluating these responses depends on the herbicide's nature and mode of action and the tested plant's susceptibility. Germination inhibitions, fresh or dry biomass of the roots or shoots, heights of the plant, root lengths, photosynthetic inhibition, the content of chlorophyll, etc., are among the critical plant measurements bioassays [79].

\section{Conclusions}

Understanding the fate and behavior of herbicide residues in the environment is vital due to the consequences of these chemicals' presence in human life. Herbicide nature, environmental conditions, and soil characteristics such as organic matter, $\mathrm{pH}$, and texture are the main factors affecting herbicides' persistence and degradation in the environment. They should be considered for appropriate herbicide risk assessment studies. Analytical methods and bioassays can detect and quantify herbicides in the soil environment, although the quantification of the total amount of herbicide concentrations in the soil could be achieved using analytical methods; however, the bioassay measures 
the bioavailable and phytotoxic portion of residues. All the factors mentioned earlier could be provided fundamental knowledge about the fate, side effects, and behavior of herbicides in the soil environment. However, it is more complicated. Many different processes such as movement and translocation, absorption and degradation, distribution, and herbicides mechanisms of action should be considered for a comprehensive understanding of pesticide behavior in the environment.

\section{Acknowledgements}

We would like to show our gratitude to the Mrs. Zoleikha Mehdizadeh (Department of Biology, Payame Noor University, 19395-3697 Tehran, Iran) for sharing her pearls of wisdom with us during the course of this review.

\section{Conflict of interest}

The authors confirm that there are no known conflicts of interest associated with this study.

\section{REFERENCES}

[1] Tudararo-Aherobo LE and Ataikiru TL (2020) Effects of chronic use of herbicides on soil physicochemical and microbiological characteristics. Microbiol. Res. J. Int., 30(5): 9-19.

[2] Peillex C and Pelletier M (2020) The impact and toxicity of glyphosate and glyphosate-based herbicides on health and immunity. J. Immunotoxicol., 17(1): 163-174.

[3] Mehdizadeh M (2016) Effect of pesticide residues on agricultural food production; A case study: Sensitivity of oilseed rape to Triasulfuron herbicide soil residue. MOJ Food Processing \& Technology, 2: 1-2.

[4] Boutin C, Strandberg B, Carpenter D, Mathiassen SK and Thomas PJ (2014) Herbicide impact on non-target plant reproduction: What are the toxicological and ecological implications? Environ. Pollut., 185: 295-306.

[5] Mehdizadeh M, Asadi GA and Delobel A (2018) Biological control potential of Spermophagus sericeus Geoffroy, 1785 (Coleoptera: Chrysomelidae) against field bindweed as the first report from Iran. J. Res. Weed Sci., 1: 40-47.

[6] Mehdizadeh M and Mushtaq W (2020) Biological control of weeds by allelopathic compounds from different plants: a bioherbicide approach. In: Egbuna C, SawickaNatural B. ed. Remedies for pest, disease and weed control. Academic Press: 107-117.

[7] Mushtaq W, Mehdizadeh M, Siddiqui MB, Ozturk M, Jabran K and Altay V (2020) Phytotoxicity of above-ground weed residue against some crops and weeds. Pak. J. Bot., 52(3): 1-10.

[8] Hossain MM (2015) Recent perspective of herbicide: Review of demand and adoption in world agriculture. J. Bangladesh Agric. Univ., 13: 19-30.

[9] Boutin C, Lee HB, Peart ET, Batchelor PP and Maguire RJ (2000) Effects of the sulfonylurea herbicide metsulfuron methyl on growth and reproduction of five wetland and terrestrial plant species. Environ. Toxicol. Chem., 19: 2532-2541.

[10] Carlsen S, Spliid NH and Svensmark B (2006) Drift of 10 herbicides after tractor spray application. 1. Secondary drift (evaporation). Chemosphere, 64: 778-786.

[11] Das AC, Chakravarty A, Sukul P and Mukherjee D (1995) Insecticides: their effect on microorganisms and persistence in rice soil. Microbiol. Res., 150: 187-194.

[12] Beard MJ (2009) Environmental chemistry in society. ed. London: Taylor \& Francis Group.

[13] Pimentel D (1995) Amounts of pesticides reaching target pests: Environmental impacts and ethics. J. Agric. Environ. Ethic., 8: $17-$ 29.

[14] Wauchope DR, Yeh S, Linders JBHJ, Kloskowski R, Tanaka K, Rubin B, Katayama A, Koerdel W, Gerstl Z, Lane M and Unsworth JB (2002) Pesticide soil sorption parameters: Theory, measurement, uses, limitations and reliability. Pest Manag. Sci., 58: 419445.

[15] Helling CS (2005) The science of soil residual herbicides. In: Van Acker RC. ed. Soil residual herbicides: Science and management. Topics in Canadian weed science. Sainte-Anne-de Bellevue, Quebec: Canadian weed science society-societe canadienne de malherbologie: 3-22.

[16] Mendes KF, Reis MR, Pereira AA, Nunes ARS, Santos CEM and Assis ACLP (2014) Sorption of oxadiazon in soils cultivated in the brazilian cerrado. Planta Daninha, 32: 215-225. 
[17] Sadegh-Zadeh F, Abd-Wahid S and Jalili B (2017) Sorption, degradation and leaching of pesticides in soils amended with organic matter: A review. Adv. Environ. Technol., 2: 119-132.

[18] Wu XM, Li M, Long YH, Liu RX, Yu YL, Fang H and Li SN (2011) Effects of adsorption on degradation and bioavailability of metolachlor in soil. J. Soil Sci. Plant Nutr., 11: 83-97.

[19] Clay DV (1993) Herbicide residues in soils and plants and their bioassay. In: Streibig JC, Kudsk P. ed. Herbicide bioassays. Boca Raton: CRC Press: 153-270.

[20] Mehdizadeh M (2015) Application of organic fertilizers for pesticide degradation from agricultural soil under controlled conditions. 5th International symposium for farming systems design, Montpellier, France: 61-62.

[21] Ray S and Singh SB (2006) Effect of soil type, soil pH, and microbial activity on persistence of clodinafop herbicide. Bull. Environ. Contam. Toxicol., 77: 260-266.

[22] Palma G, Demanet R, Jorquera M, Mora ML, Briceño G and Violante A (2015) Effect of pH on sorption kinetic process of acidic herbicides in a volcanic soil. J. Soil Sci. Plant Nutr., 15: 549-560.

[23] Quan G, Yin C, Chen T and Yan J (2015) Degradation of herbicide mesotrione in three soils with differing physicochemical properties from China. J. Environ. Qual., 44: 1631-1637.

[24] Rousk J, Brookes PC and Baath E (2009) Contrasting soil pH effects on fungal and bacterial growth suggest functional redundancy in carbon mineralization. Appl. Environ. Microbiol., 75: 1589-1596.

[25] Singh BK, Walker A, Morgan JA and Wright DJ (2003) Effects of soil pH on the biodegradation of chlorpyrifos and isolation of a chlorpyrifos-degrading bacterium. Appl. Environ. Microbiol., 69: 5198-206.

[26] Wlodarczyk M and Siwek H (2017) The influence of humidity and soil texture on the degradation process of selected herbicides immobilized in alginate matrix in soil under laboratory conditions. Pol. J. Soil Sci., 50: 121-130.

[27] Reinhardt CF and Nel PC (1993) The influence of soil type, soil water content and temperature on atrazine persistence. S. Afr. J. Plant Soil, 10: 45-49.

[28] Kucharski M and Sadowski J (2009) Degradation of Ethofumesate in soil under laboratory conditions. Pol. J. Environ. Stud., 18: 243-247.

[29] Long YH, Li RT and Wu XM (2014) Degradation of S-metolachlor in soil as affected by environmental factors. J. Soil Sci. Plant Nutr., 14: 189-198.

[30] Nunan N, Leloup J, Ruamps LS, Pouteau V and Chenu C (2017) Effects of habitat constraints on soil microbial community function. Sci. Rep., 7: 4280.

[31] Cessna AJ, Knight D, Ngombe D and Wolf TM (2017) Effect of temperature on the dissipation of seven herbicides in a biobed matrix. Can. J. Soil. Sci., 97: 717-731.

[32] Williams GM, Kroes R and Munro IC (2000) Safety evaluation and risk assessment of the herbicide roundup and its active ingredient, glyphosate, for humans. Regul. Toxicol. Pharmacol., 31: 117-165.

[33] Primel EG, Zanella R, Kurz MHS, Gonçalves FF, Martins ML, Machado SLO and Marchesan E (2007) Risk assessment of surface water contamination by herbicide residues: monitoring of propanil degradation in irrigated rice field waters using HPLC-UV and confirmation by GC-MS. J. Braz. Chem. Soc., 18: 585-589.

[34] Lu W, Li L, Chen M, Zhou ZF, Zhang W, Ping SZ, Yan YL and Wang J (2013) Genome-wide transcriptional responses of Escherichia coli to glyphosate, a potent inhibitor of the shikimate pathway enzyme 5-enolpyruvylshikimate-3-phosphate synthase. Mol. Biosyst., 9: 522-530.

[35] Ensminger MP, Budd R, Kelley KC and Goh KS (2013) Pesticide occurrence and aquatic benchmark exceedances in urban surface waters and sediments in three urban areas of California, USA, 2008-2011. Environ. Monit. Assess., 185: 3697-3710.

[36] Mehdizadeh M, Alebrahim MT, Roushani M and Streibig JC (2016) Evaluation of four different crops' sensitivity to sulfosulfuron and tribenuron methyl soil residues. Acta Agric. Scand. B Soil Plant Sci., 66: 706-713.

[37] Wang H, Liu W, Zhao K, Yu H, Zhang J and Wang J (2018) Evaluation of weed control efficacy and crop safety of the new HPPDinhibiting herbicide-QYR301. Sci. Rep., 8: 7910.

[38] Arora A and Tomar SS (2019) Persistence of herbicides in pearlmillet-wheat cropping system in madhya pradesh. In: Sondhia S, Choudhury P and Sharma A. Herbicide residue research in India. Environmental chemistry for a sustainable world. ed. [12]. Singapore: Springer: $277-287$.

[39] Singh H, Singh NB, Singh A, Hussain I and Yadav V (2016) Physiological and biochemical effects of salicylic acid on Pisum sativum exposed to isoproturon. Arch. Agron. Soil Sci., 62: 1425-1436. 
Please cite this article as

Mehdizadeh et al. Reviews in Agricultural Science, 9: 157-167, 2021

https://dx.doi.org/10.7831/ras.9.0_157

[40] Olszyk D, Blakeley-Smith M, Pfleeger T, Lee EH and Plocher M (2013) Effects of low levels of herbicides on prairie species of the Willamette Valley, Oregon. Environ. Toxicol. Chem., 32: 2542-2551.

[41] Jiang Z, Ma B, Erinle KO, Cao B, Liu X, Ye S and Zhang Y (2016) Enzymatic antioxidant defense in resistant plant: Pennisetum americanum (L.) K. Schum during long-term atrazine exposure. Pestic Biochem. Physiol., 133: 59-66.

[42] Mehdizadeh M, Izadi-Darbandi E, Naseri Pour Yazdi MT, Rastgoo M, Malaekeh-Nikouei B and Nassirli H (2019) Impacts of different organic amendments on soil degradation and phytotoxicity of metribuzin. Int. J. Recycl. Org. Waste Agric., 8: 113-121.

[43] Jiang L and Yang H (2009) Prometryne-induced oxidative stress and impact on antioxidant enzymes in wheat. Ecotoxicol. Environ. Saf., 72(6): 1687-1693.

[44] Fuscaldo F, Bedmar F and Monterubbianesi G (1999) Persistence of atrazine, metribuzin and simazine herbicides in two soils. Pesq. Agropec. Bras., 34(11).

[45] Henderson CWL and Webber MJ (1993) Phytotoxicity of several pre-emergence and post-emergence herbicides to green beans (Phaseolus vulgaris). Aust. J. Exp. Agric., 33(5): 645-652.

[46] Mehdizadeh M and Gholami-Abadan F (2018) Negative effects of residual herbicides on sensitive crops: Impact of rimsulfuron herbicide soil residue on sugar beet. J. Res. Weed Sci., 1: 1-6.

[47] Nelemans JB, vanWijngaarden RPA, Roessink I and Arts GHP (2017) Effects of the herbicide metsulfuron-methyl on a plant community, including seed germination success in the F1 generation. Front. Environ. Sci., 5: 10.

[48] Mesarović J, Srdić J, Mladenović-Drinić S, Dragičević V, Simić M, Brankov M and Milojković-Opsenica D (2019) Evaluation of the nutritional profile of sweet maize after herbicide and foliar fertilizer application. J. Cereal Sci., 87: 132-137.

[49] Kaya A and Doganlar ZB (2016) Exogenous jasmonic acid induces stress tolerance in tobacco (Nicotiana tabaccum) exposed to imazapic. Ecotoxicol. Environ. Saf., 124: 470-479.

[50] Kaur P, Kaur P, Kaur N, Jain D, Singh K and Bhullar MS (2020) Dissipation and phytotoxicity of imazethapyr and imazamox in soils amended with $\beta$-cyclodextrin-chitosan biocomposite. Sci. Total Environ., 735: 139566.

[51] Bovey RW and Senseman SA (1998) Response of food and forage crops to soil-applied imazapyr. Weed Sci., 46(5): 614-617.

[52] Florido FG, Monquero PA, Ribeiro-Dias AC and Tornisielo V (2014) The absorption and translocation of imazaquin in green manures. Acta Sci. Agron., 36(3): 291-300.

[53] Lancaster ZD, Norsworthy JK and Scott RC (2018) Residual activity of ACCase-inhibiting herbicides on monocot crops and weeds. Weed Technol., 32(4): 364-370.

[54] Villaverde JJ, Santín-Montanyá MI, Morán BS, Alonso-Prados JL and Sandín-España P (2018) Assessing the effects of alloxydim phototransformation products by QSAR models and a phytotoxicity study. Molecules., 23: 993-2006.

[55] Noshadi M, Foroutani A and Sepaskhah A (2017) Analysis of clodinafop-propargyl herbicide transport in soil profile under vetiver cultivation using HYDRUS-1D and modified PRZM-3 models. Toxicol. Open Access, 3(1): 120.

[56] Cenkci S, Yildiz M, Cigerci IH, Bozdag A, Terzi H and Terzi ESA (2010) Evaluation of 2,4-D and dicamba genotoxicity in bean seedlings using comet and RAPD assays. Ecotoxicol. Environ. Saf., 73: 1558-1564.

[57] Bohnenblust EW, Vaudo AD, Egan JF, Mortensen DA and Tooker JF (2016) Effects of the herbicide dicamba on nontarget plants and pollinator visitation. Environ. Toxicol. Chem., 35(1): 144-151.

[58] Žaltauskaitė J and Kišonaite G (2014) The effects of phenoxy herbicide MCPA on non-target vegetation in spring wheat (Triticum aestivum L.) culture. Biologija., 60(3): 148-154.

[59] Rahman A, Dyson CB and Burney B (1978) Effect of soil organic matter on the phytotoxicity of soil-applied- field studies. N.Z. J. Exp. Agric., 6: 69-75.

[60] Ahmed S and Chauhan BS (2015) Efficacy and phytotoxicity of different rates of oxadiargyl and pendimethalin in dry-seeded rice (Oryza sativa L.) in Bangladesh. Crop Prot., 72: 169-174.

[61] Chauhan BS and Johnson DE (2011) Growth response of direct-seeded rice to oxadiazon and bispyribac-sodium in aerobic and saturated soils. Weed Sci., 59(1): 119-122.

[62] Poudyal S, Owen JS, Fernandez RT and Cregg B (2020) Sensitivity of hydrangea paniculata plants to residual herbicides in recycled irrigation varies with plant growth stage. Water, 2(5): 1402.

[63] Kandel YR, Mueller DS, Legleiter T, Johnson WG, Young BG and Wise KA (2018) Impact of fluopyram fungicide and preemergence herbicides on soybean injury, population, sudden death syndrome, and yield. Crop Prot., 106: 103-109.

[64] Shrestha A, Thapa B and Kandel S (2019) Assessment of different weed management practices in yield and yield attributes in summer maize in inner Terai of Nepal. J. Res. Weed Sci., 2(3): 224-229. 
[65] Widayat D, Sumekar Y, Wahyudin A, Yuwariah Y and Farida CM (2019) Effect of various dosage of ammonium glufosinate herbicide on suppressing weeds and growth and yield of corn. J. Res. Weed Sci., 2(2): 90-102.

[66] Mehdizadeh M (2019) Sensitivity of oilseed rape (Brassica napus L.) to soil residues of imazethapyr herbicide. Int. J. Agric. Environ. Food Sci., 3(1): 46-49.

[67] Filkowski J, Besplug J, Burke P, Kovalchuk I and Kovalchuk O (2003) Genotoxicity of 2, 4-D and dicamba revealed by transgenic Arabidopsis thaliana plants harboring recombination and point mutation markers. Mutat. Res., 542: 23-32.

[68] Mehdizadeh M, Alebrahim MT and Roushani M (2017) Determination of two sulfonylurea herbicides residues in soil environment using HPLC and phytotoxicity of these herbicides by lentil bioassay. Bull. Environ. Contam. Toxicol., 99: 93-99.

[69] Janaki P, Bhuvanadevi S, Dhananivetha M, Murali AP and Chinnusamy C (2018) Persistence of quizalofop ethyl in soil and safety to ground nut by ultrasonic bath extraction and HPLC-DAD detection. J. Res. Weed Sci., 1(2): 63-74.

[70] Zhang L, Yuac R, Yu Y, Wang C and Zhang D (2019) Determination of four acetanilide herbicides in brown rice juice by ionic liquid/ionic liquid-homogeneous liquid-liquid micro-extraction high performance liquid chromatography. Microchem. J., 146: 115-120.

[71] Haskis P, Mantzos N, Hela D, Patakioutas G and Konstantinou I (2019) Effect of biochar on the mobility and photodegradation of metribuzin and metabolites in soil-biochar thin-layer chromatography plates. Int. J. Environ. Anal. Chem., 99: 310-327.

[72] Dong X, Liang S, Shi Z and Sun H (2016) Development of multi-residue analysis of herbicides in cereal grain by ultra-performance liquid chromatography-electrospray ionization-mass spectrometry. Food Chem., 192: 432-440.

[73] Yu Q, Zhang P, He Y, Xu Z, He X, Hu Y, Zhang H and He L (2019) Dissipation dynamics and residue of four herbicides in paddy fields using HPLC-MS/MS and GC-MS. Int. J. Environ. Res. Public Health, 16: 236.

[74] Tian H, Fu H, Xu C and Xu C (2019) Simultaneous determination of three herbicides in honey samples using an aqueous biphasic system coupled with HPLC-MS/MS. Chromatographia, 82: 1571-1577.

[75] Daniel D and do-Lago CL (2019) Determination of multiclass pesticides residues in corn by QuEChERS and capillary electrophoresis tandem mass spectrometry. Food Anal. Method, 12: 1684.

[76] Mehdizadeh M (2014) High performance liquid chromatographic determination of an asymmetrical triazine herbicide from soil. Int. J. Farm Alli. Sci., 3: 1201-1205.

[77] Sondhia S and Singh PK (2018) Bioefficacy and fate of pendimethalin residues in soil and mature plants in chickpea field. J. Res. Weed Sci., 1(1): 28-39.

[78] O'Sullivan J (2005) Grower-friendly bioassay for imazethapyr. In: Van Acker RC. Soil residual herbicides: Science and management. Topics in Canadian weed science. ed. [3]. Saine-Anne-de Bellevue, Quebec: Canadian Weed Science Society: 8188.

[79] Al-Gburi BKH, Al-Sahaf FH, Al-Fadhal FA and Del-Monte JP (2019) Evaluation of different treatments on break seed dormancy of Dodder (Cuscuta campestris Yunck). J. Res. Weed Sci., 2(2): 168-179. 